\title{
Implementing a Cooperative E-Learning Model by Virtual Interviews with Native Speakers
}

\author{
Febrianti Nurul Hidayah¹ \\ febrianti.nurul.hidayah@uii.ac.id
}

\begin{abstract}
This study aimed to define the impact of the cooperative learning model through virtual interviews with native speakers on learning outcomes and student perceptions in English course. This strategy is applied to overcome obstacles in the absence of offline learning (face-to-face in class) during the covid-19 pandemic; thus, online learning methods need to be modified to optimize student ability in English. A total of 135 students were given a questionnaire to determine their opinion about the virtual interviews and their learning progress. Half of the students taught through the virtual interview with native speakers (experimental group) and the others without native speakers (control group). Results showed that both groups showing increases in speaking confidence and their perception of the learning process, but the experimental group's mean percentage was higher than in the control group. Therefore, the cooperative learning model's implementation can lead to positive outcomes since they could engage students in the English learning process. The implication of this study calls for the cooperative learning model implementation did not only make students active and motivated in learning, but also can improve the effectiveness and quality of learning.
\end{abstract}

Keywords: $\quad$ virtual interview, native speaker, online learning, cooperative learning

Abstrak: $\quad$ Penelitian ini bertujuan untuk mengetahui pengaruh hasil belajar dan persepsi siswa terhadap penggunaan model pembelajaran kooperatif melalui wawancara virtual dengan native speaker pada mata kuliah bahasa Inggris. Strategi ini diterapkan untuk mengatasi kendala tidak adanya pembelajaran offline (tatap muka di kelas) selama pandemi Covid-19; Oleh karena itu, metode pembelajaran online perlu dimodifikasi untuk mengoptimalkan kemampuan siswa dalam berbahasa Inggris. Sebanyak 135 siswa diberi kuesioner untuk mengetahui pendapat mereka tentang wawancara virtual dan kemajuan belajar mereka. Setengah dari siswa diberikan tugas melalui wawancara virtual dengan penutur asli (kelompok eksperimen) dan yang lainnya tanpa penutur asli (kelompok kontrol). Hasil penelitian menunjukkan bahwa kedua kelompok menunjukkan peningkatan kepercayaan diri berbicara dan persepsi mereka tentang proses pembelajaran, tetapi persentase rata-rata kelompok eksperimen lebih tinggi daripada kelompok kontrol. Oleh karena itu, penerapan model pembelajaran kooperatif dapat memberikan hasil yang positif karena dapat melibatkan siswa dalam proses pembelajaran bahasa Inggris. Implikasi dari penelitian ini menghimbau agar penerapan model pembelajaran kooperatif tidak hanya menjadikan siswa aktif dan termotivasi dalam pembelajaran, tetapi juga dapat meningkatkan keefektifan dan kualitas pembelajaran.

Kata Kunci: $\quad$ wawancara virtual, native speaker, pembelajaran daring, pembelajaran kooperatif

Submitted: January $2021 \quad$ Reviewed: February $2021 \quad$ Accepted: March $2021 \quad$ Published: March 2021

\footnotetext{
1 Faculty of Industrial Technology, Universitas Islam Indonesia
} 
earning before the Covid-19 pandemic focused more on offline meetings or face-to-face classrooms. With technology, the blended learning method is increasingly being applied to suit students and lecturers in advancing distance learning technology. Blended learning itself is a learning model that is combined face-to-face and electronic use (So \& Brush, 2008; Sutisna, 2016). Meanwhile, recently due to the Covid-19 pandemic, learning is required to be fully online which does not allow face-to-face meetings in class, thus e-learning is a mandatory choice for lecturers and students and the methods of how to carry the online learning going well has became an important issue in education topics. One of the offline learning methods that can be implemented in online learning is cooperative learning which applies the value of student-centered learning (SCL). This cooperative learning strategy aims to apply knowledge with a professional attitude, and students can work together in learning (Nugroho, 2019). The value of cooperative learning is the same as that stated in the Regulation of the Minister of Education and Culture of the Republic of Indonesia Number 49 of 2014 concerning National Higher Education Standards, article 11 paragraph 1 which states that "The characteristics of the learning process consist of interactive, holistic, integrative, scientific, contextual characteristics. thematic, effective, collaborative, and student-centered" (Minister of Education and Culture of the Republic of Indonesia, 2014). According to Kolawole (2008) and Nugroho et.al (2009), with the existence of cooperative learning, in other words collaborative, it not only gives a sense of responsibility to the group but also hones students' social skills which in English courses require these points. This is in line with the study of Kismanto (2019) which concluded that cooperative learning could provide opportunities for students to express ideas or ask questions so that they can creating active student learning. Ningtyas dan Wuryani (2017) added that one of the advantages of cooperative learning is the effectiveness of the process and learning outcomes.

The student-centered learning method in cooperative learning places students as adult learners so that students are responsible for being able to learn effectively and efficiently. (Purwaningsih, 2020; Rohyami \& Huda, 2019). Academic Year 2020/2021 students who are Generation Z, based on the study of Tang dan Chaw (2013), have the characteristics of heavy technology users so that online learning no longer requires significant adjustments because they are familiar with online activities from an early age. Specifically, the innovative concept of developing online learning with cooperative learning, the studentcentered learning method will use project learning or project-based learning ( $\mathrm{PJBL}$ ) which is a development of John Dewey's thinking in the form of learning by doing. (Merdekawati, 2019). Erdem (2012) stated that being demanded to produce real work, PjBL positively impacts students such as interest, contextual understanding and increased academic achievement.

Based on the learning concept theory above, the English course adapts it as the main principle in online learning. Online learning makes students as independent learners who are responsible for the learning process, so lecturers as facilitators need to prepare lesson plans, provide study materials and provide assistance during learning (Adi, 2018). Some earlier studies about interview in English class have been conducted where most of them were in class (offline or face-to-face learning). Three of them observed with the three-step-interview technique were Hendriani (2018), Permanasari (2014) and Ratnawati et al. (2018). Three-step-interview technique was first introduced by Spencer Kagan in 1989 which was one of the cooperative learning strategies. Students interview each other in pairs, one way and the other; then the students share with the group information they learned from their interview (Kagan, 1989). A study of Ratnawati et al. (2018) implemented three-step-interview (TSI) and numbered heads together (NHT) which result was TSI performed better than NHT to improve the students' speaking skills in English. Moreover, Hendriani (2018) and Permanasari (2014) applied TSI for tenth-grade high school students in English course. Both of them experimented with pre-test and post-test to observe improvement of speaking skills, and their results showed that post-test scores were higher than pre-test which meant TSI did enhance their speaking capability in English. Another face-to-face interview in an 
English study was conducted by Maca (2020). He experimented with two types of interview, pairs and groups, and a control group. The results were that all participants in pairs and group interviews were very active and more confident, while the control group was less active and felt shy (Maca, 2020).

Other studies about interview but in online media were conducted by some researchers such as Authar \& Afandi (2020) and Baron (2020) They observed their students speaking skills with pairs and group interviews through video conference. Baron (2020) stated that his students preferred using Zoom Cloud and Google Hangout Meetings to improve their speaking skills through dialogue with their classmate, while Youtube was chosen to do monologue by recording and uploading it thus the lecturer could examine their speaking capability well. In the other hand, Authar \& Afandi (2020) added that using Task Based Language Instruction to assign the students for interviewing in pairs through online video conference had some benefits. They explained this interview task built more confidence on students in learning process and developed students' speaking skills. This statement is supported by Teng (2020) in which the students in the pairs worked less vocabularies knowledge than in groups. Nevertheless, activities in pairs obtained more competence than individual activities.

In conclusion, those studies above were held to investigate the use of interviews in English teaching in general, both offline and online. Thus the current study showed the novelty on the interviewbased task which aimed to implement cooperative learning in the form of an online group interview in which native speakers were involved as the interviewee. Moreover, it also intended to observe the improvement of speaking skills after interview tasks and students' perception of an online group interview with native speakers in the process of English learning. This study's results would benefit for EFL teachers in choosing an interview-based task to consider involving foreign or native speakers through online video conference.

\section{RESEARCH METHODS}

The current research employed an embedded mixed method design which were qualitative and quantitative with an experimental research of group interview techniques. It also conducted a survey method which aimed at exploring characteristics of groups using Google forms as questionnaire then analyzed quantitatively through a spreadsheet. (Ary et al., 2010; Fraenkal et al., 2012). The students were divided in group of 5 with the experimental group were those who interviewed native speakers for their team's assignment, while the control group interviewed their own member. The assignment was explained in the first day of lecture, and they were given five weeks to arrange time, topic and wellstructured questions which their team should be discussed about. They conducted the interviews by them self via Zoom Meeting Clouds, recorded and edited as creative as they could. Then they upload it to their own Youtube Channel to be assessed by the teacher and their classmate. In the seventh week, they were given 15 minutes of pitch or short presentation about their team's work on Zoom Meetings Cloud with the other students had chances to ask and give feedbacks to the team who were presenting.

There were in total of 135 students which the treatment group was 59 students and 76 students were as a control group. They are first-year students of Chemical Engineering Department, Faculty of Industrial Technology, Universitas Islam Indonesia. The improvement of speaking skills after interview tasks were graded based on their engagement during the presentation after interview, and students' perception of online group interview with native speakers in the process of English learning were questioned through Google Forms. The gathered data were then stored in the spreadsheet. The students' responses as a quantitative data were evaluated using as percentages, means and standard deviation as descriptive statistics which were applied to determine the effectiveness of cooperative learning in the form of group online interview on students speaking comprehension and perception of the online learning process. 
The interviews were conducted by students in a group of 5 and the interviewees were native speakers (for treatment samples) and their own group members (for control samples). The lecturer gave optional topics to discuss and they were given 30 minutes of interview. Prior to the interview, students must divide their roles; thus, each member had the same duty and right to ask and respond in the interview process. The interviews were conducted online via Zoom Meeting and recorded and edited by them. They were given five weeks to do all the tasks properly and in the end of the semester, they had to present their work in 15 minutes of pitch, including the results, summary, advantages and difficulties on prior-during-after the assignment. The other groups might ask and give feedback directly after the presentation. These processes were then evaluated by the researcher how the students engaged during question-answer and feedback session, and compared to their activeness during interview as well. The experimental group of 59 students showed more engagement during the presentation, of which $67,79 \%$ of them asked and answered the questions then gave feedback. In the other hand, the control group of 76 students were less attracted which $56,57 \%$ of them contributed during Q\&A session.

The further aspects to concern in classroom vibrant are including classroom interactions, and the enjoyment of interview process. Table 1 illustrated the results of these points.

Table 1. Students' perception of classroom vibrant

\begin{tabular}{|c|c|c|c|c|c|c|c|c|c|c|c|}
\hline \multirow[b]{2}{*}{ Item } & \multirow[b]{2}{*}{ Statement } & \multicolumn{6}{|c|}{ Experimental Group } & \multicolumn{4}{|c|}{ Control Group } \\
\hline & & $\begin{array}{l}\text { DA } \\
(\%)\end{array}$ & $\underset{(\%)}{N}$ & $\begin{array}{c}A \\
(\%)\end{array}$ & M & S.D. & $\begin{array}{l}\text { DA } \\
(\%)\end{array}$ & $\underset{(\%)}{N}$ & $\begin{array}{c}A \\
(\%)\end{array}$ & M & S.D \\
\hline 1 & $\begin{array}{l}\text { The interviews } \\
\text { were promoting } \\
\text { students' } \\
\text { interaction and } \\
\text { cooperation. }\end{array}$ & 0,00 & 45,76 & 54,24 & 2,54 & 0,50 & 0,00 & 53,95 & 46,05 & 2,46 & 0,50 \\
\hline 2 & $\begin{array}{l}\text { Interview } \\
\text { sessions made } \\
\text { the class more } \\
\text { enjoyable and } \\
\text { interactive even } \\
\text { through online } \\
\text { media }\end{array}$ & 0,00 & 15,25 & 84,75 & 2,85 & 0,36 & 0,00 & 18,42 & 81,58 & 2,82 & 0,39 \\
\hline
\end{tabular}

Note : DA: disagree, N: neutral, A: agree, M: mean, S.D. : standard deviation

Based on the results in Table 1, the students of the experimental and control groups had a slightly different perspective on classroom dynamics. The experimental group agreed more than half $(54,24 \%)$ that the interview task made the students interact with each other and encourage them to cooperate in a group. In comparison, half of the control group (53,95\%) chose neutral (either agree or disagree). On the other hand, for the enjoyable process of learning, both of groups mostly agreed that the interview, either with or without native speakers were enjoyable. However, the percentage is slightly higher in the experimental group which reached $84,75 \%$ while the control was $81,58 \%$. 
This study questioned about how cooperative learning on interview task with native speakers might increase their motivation to learn English more. Therefore, the questionnaire was given and Table 2 represents the results.

Table 2. Students' views on aspects of motivation and perceived learning

\begin{tabular}{|c|c|c|c|c|c|c|c|c|c|c|c|}
\hline \multirow[b]{2}{*}{ Item } & \multirow[b]{2}{*}{ Statement } & \multicolumn{6}{|c|}{ Experimental Group } & \multicolumn{4}{|c|}{ Control Group } \\
\hline & & $\begin{array}{l}\text { DA } \\
(\%)\end{array}$ & $\begin{array}{l}\mathrm{N} \\
(\%)\end{array}$ & $\begin{array}{l}A \\
(\%)\end{array}$ & M & S.D. & $\begin{array}{l}\text { DA } \\
(\%)\end{array}$ & $\begin{array}{l}N \\
(\%)\end{array}$ & $\begin{array}{l}A \\
(\%)\end{array}$ & M & S.D \\
\hline 3 & $\begin{array}{l}\text { Interview task } \\
\text { increases the } \\
\text { students' } \\
\text { motivation to } \\
\text { learn more } \\
\text { English }\end{array}$ & 0,00 & 11,84 & 88,16 & 2,88 & 0,33 & 1,69 & 20,34 & 77,97 & 2,76 & 0,46 \\
\hline 4 & $\begin{array}{l}\text { Interview task } \\
\text { improve the } \\
\text { confidence to } \\
\text { speak in English }\end{array}$ & 0,00 & 27,63 & 72,37 & 2,73 & 0,45 & 1,69 & 40,68 & 57,63 & 2,57 & 0,52 \\
\hline
\end{tabular}

Based on statement number 3 in Table 2, a vast majority of students in the experimental group $(88,16 \%)$ reported that interview task promoted the students' motivation to learn English more, where only a small percentage of respond $(11,84 \%)$ expressed neutral respond. On the other hand, the control group had $1,69 \%$ of students answering disagree, which meant the interview task did not raise their learning motivation. The survey also asked 'Interview task improve the confidence to speak in English'. As expected, the experimental group had a higher percentage $(72,37 \%)$ on self-confidence than the control group $(57,63 \%)$ where they chose to say agree on this statement. Similar to question number 3 , some of students in the control group $(1,69 \%)$ stated their disagreement about their improvement on confidence to speak in English.

This present research aimed to generate a description of English course students' views on the use of online interview with native speakers. The students were divided to be two groups: experimental and control groups. The experimental groups interviewed native speakers while control groups interviewed their friends in their own group or their relative who can speak English well. The findings showed positive feedbacks concerning the interview assignment on the aspects of classroom vibrant, motivation and perceived learning experience. The factual data obtained from students' engagement for speaking in the class during Q\&A session indicated that both of the groups had more than half showing confidence on asking, answering and giving feedbacks with $67,79 \%$ of the experimental groups and $56,57 \%$ from the control group. These results supply to the empirical points of findings from the previous studies, Maca (2020) and Authar\&Afandi (2020) where students gained more confidence after the interview tasks were conducted. That might due to the opportunities provided by interview in terms of facilitating speaking-learning access as they might imagine realities to talk with foreign people, either for formal language tests (such as IELTS) or in their daily activities.

Based on the first statement of classroom vibrant in Table 1, it is thoughtful to presume that the students felt that the interviews had a benefit to encourage them to interact with the team and classmates even they only met virtually and never faced each other in the real classroom. In the same direction as 
statement 1, statement 2 evaluated the classroom dynamics whether the interview assignment made the class more enjoyable or not. The vast majority of both groups agreed which more than $80 \%$ of students enjoyed the learning process. Moreover, a complete assignment flows helped to foster the studentteacher interactivity even through online media. It is shown in Figure 1 that the experimental group which consisted of 5 students and a native speaker, performed well-organized virtual interview through Zoom Cloud Meeting and they enjoyed the learning process. These findings complement to the previous work of Baron (2020) that using an online media such as Zoom Cloud Meetings to perform dialogue tasks is preferred by students while also improve their speaking skills.

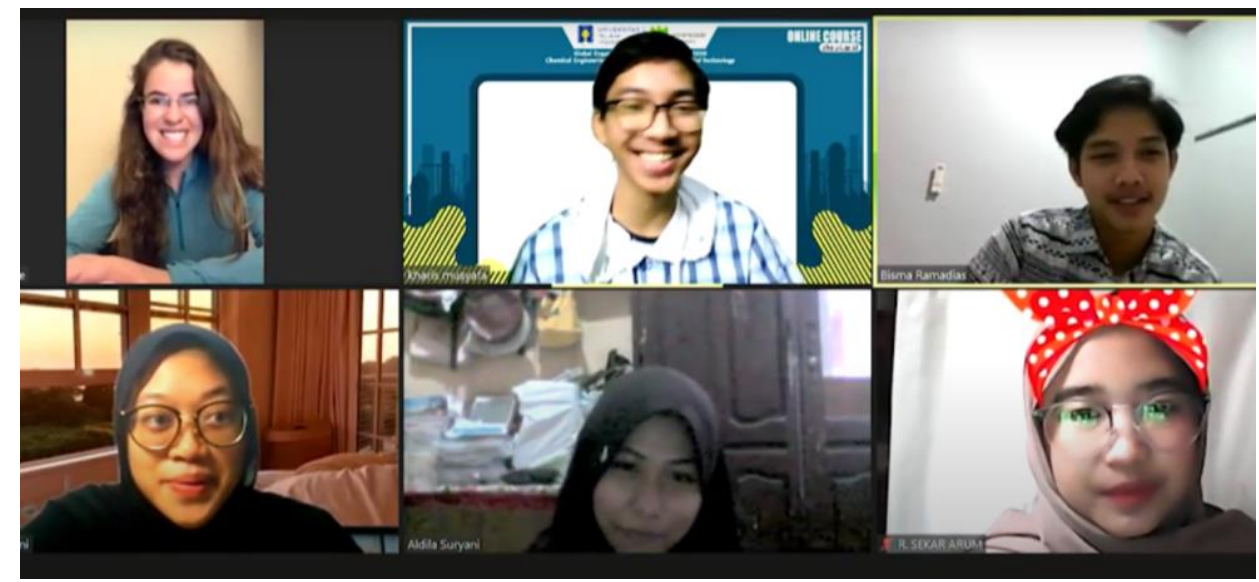

Figure 1. One of experimental groups' virtual interviews shows the students enjoyed the interview process with a native speaker

When asked to respond the item number 3 , the majority students in the experimental group believe that virtual interviews with native speakers affected the students' learning motivation level. The control group mostly agreed whereas a small percentage of participants gave negative responses. These results provided consistency with the study findings of contemporary studies (Anora, 2020; Kassem, 2018), assuring that the interview-based-tasks positively affected the motivation level of the students. Anora (2020) added that interview tasks in English speaking lessons could offer a huge deal in developing basic interactive skills that are necessary for students' life. Moreover, Kassem (2018) agreed that through interview, students' speaking proficiency and motivation significantly increased.

Beside the survey by numbers shown in item 3 , students were asked to describe how the interview motivate them. One of the experimental group member, Maharani stated:

"the great impression was that when the lecturer gave me the task of interviewing strangers, it really helped me because I had never previously spoken to foreigners in English."

The other student, Hanifah who was in the experimental group also added:

"it was so exciting. The most favorite task was the interview task, but it was a bit difficult to work in a team. This task has improved my knowledge and confidence."

In the other hand, even the control group has lower percentage in item 3, most of them stated their higher motivation on the learning progress. As Farhan, one of the control group member said:

"the impression during this lesson is very pleasant because from the task, we can hone our skills in speaking English and also very motivating to learn English more deeply"

It is clear that the students in both groups were experiencing a well process of learning which motivate them to learn more in English, even they obtained some obstacles such as in the team work 
management. The definition of motivation was described by some researchers such as Ushioda (2008), McCombs (1994) and Vygotsky (1978). Ushioda (2008) stated that motivation could be determined as the matter that can move an individual to decide some choices, to get in role to some actions and to persist in his action. He added that in the language learning, the theories of cognitive for the learner's motivation could shape the extrinsic and intrinsic motivation. Moreover, the intrinsic motivation can lead to a more effective process of learning. On the other hand, McCombs (1994) believed that a learner might have ability to improve their motivational self-regulation that based on the level to which the learners consider themselves as agent who are able to construct their thought, beliefs, goals, as well as expectations to build their motivation. With their control to motivate themselves, it is expected that will lead to more maximum performance and effort. In contrast with self-motivation, Vygotsky (1978) declared motivation is related to the social dimension of motivation. It is called as Vygotskian sociocultural theory, where the motivation comes from social interaction which coming from within the student as the main part of learning and consider social interaction and engagement as factors that promote their motivation (Jafari et al., 2020). It is in one direction of this research's aim, that is in order to develop the students' motivation, the social interaction was conducted through group-interview assignment.

For the last statement of the questionnaire, students felt that the interview task surely enhanced their confidence to speak in English for that $72,37 \%$ in the experimental group, while the others defined neutral response which either agree or disagree. The control group showed much lesser than the experimental group, whereas only half of them agreed $(n=44,57,63 \%)$ that interview improve their confidence, while the rest of them were neutral $(40,68 \%)$ and a small percentage responded negatively. It was might due to the less attractive interview since they interviewed their own group's members while the experimental group had native speakers as interviewees.

In general, analyzing from this present research's results, it can be strongly clarified that the virtual interview with native speakers gave benefits for teaching-learning processes. However, the teacher should also consider English basic knowledge of each student, since some students were showing they were advanced or fluent in English speaking while the others might be still in intermediate levels or even poor. Thus this implementation of a virtual interview is expected to encourage them to practice more so at the end, they would be in the same levels of confidence and ability. Since the interview assignment has high impact on students' participation, student-student and student-teacher interaction, as well as self-motivation, it is the teachers' responsibility to evaluate and re-conceptualize how the interview would be going to be merged to successfully stimulate the students' comprehension development. The cooperative learning method in this study also resulted in line with study of Kismanto (2019) which stated that the cooperative learning did not only enhance the understanding of given study materials but also has improved the participation of students during learning process.

\section{CONCLUSION AND RECOMMENDATION}

As been previously described, this current research was conducted to fulfill the research question about how a cooperative e-learning model with virtual interviews with native speakers in EFL classrooms at university level might impact the students' perception on learning process. Overall, after conducting careful analyses on students' engagement after the task and the data gathered from questionnaire through Google Forms, it was evident that the results demonstrate a potent indicator that the students obtained high-level acceptance conceiving interview-based-tasks as the promising activity to improve the English learning process. The majority of students responded that it could provide a positive energy to have a noticeable impact on classroom vibrant, producing the students' engagement and motivation. Nevertheless, several limitations should be considered as well. First, the students involved in this research were university students who are in the first semester and they never met each other in real life because of the covid-19 pandemic; therefore, the connections among classmates had not been established well. Second, the students had different English basic knowledge; thus, some were not 
confident yet to speak up and felt shy. Further research should re-concept and re-group the students based on the level of their English skills. Observing interview-based-task as one of the cooperative learning processes from the lecturers' point of view would also be necessary for developing online-based learning systems.

\section{REFERENCES}

Adi, A. N. (2018). Pengembangan Aktivitas Pembelajaran Daring Melalui Blended Learning. 1-48.

Anora, J. (2020). Modern approaches in teaching speaking.

Ary, D., Jacobs, L. C., Sorensen, C., \& Razavieh, A. (2010). Introduction to research in education eight edition. Wadsworth: Cengage Learning.

Authar, N., \& Afandi, M. D. (2020). The use of task-based language instruction through online video teleconference application in teaching speaking skill on english department. 9(November), 286298.

Baron, R. (2020). Students' Perception on Online Application in Speaking Skill. VELES Voices of English Language Education Society, 4(2), 213-221. https://doi.org/10.29408/veles.v4i2.2543

Erdem, E. (2012). Examination of the effects of project based learning approach on students' attitudes towards chemistry and test anxiety. World Applied Sciences Journal, 17(6), 764-769.

Fraenkal, J. R., Wallen, N. E., \& Hyun, H. H. (2012). Content analysis. How to design and evaluate research in education. 8th edn. New York: McGraw-Hill, 477-504.

Hendriani, L. (2018). Three Steps Interview in Teaching Speaking Skill for EFL Learners. VELES Voices of English Language Education Society, 2(1), 38-43. https://doi.org/10.29408/veles.v2i1.607

Jafari, S., Jafari, S., \& Kafipour, R. (2020). How Does She Learn English? A Case of a Successful Blind Language Learner. Vision: Journal for Language and Foreign Language Learning, 9(2), 131. https://doi.org/10.21580/vjv10i16727

Kagan, S. (1989). The Structural Approach to Cooperative Learning.

Kassem, M. A. M. (2018). Improving EFL Students' Speaking Proficiency and Motivation: A Hybrid Problem-based Learning Approach. Theory and Practice in Language Studies, 8(7), 848. https://doi.org/10.17507/tpls.0807.17

Kismanto, K. (2019). Peningkatan Pemahaman dan Keaktifan Siswa Melalui Penerapan Model Pembelajaran Kooperatif Tipe TAI (Teams Assisted Individualization) di SMA Negeri 6 Surakarta. Teknodika, 17(1), 34-48.

Kolawole, E. B. (2008). Effects of competitive and cooperative learning strategies on academic performance of Nigerian students in mathematics. Educational Research and Reviews, 3(1), 3337.

Maca, S. (2020). Teaching English Speaking Skill through Pair and Group Interview Techniques. Ethical Lingua: Journal of Language Teaching and Literature, 7(2), 329-337. https://doi.org/10.30605/25409190.192

McCombs, B. L. (1994). Strategies for assessing and enhancing motivation: Keys to promoting selfregulated learning and performance.

Merdekawati, K. (2019). Penerapan pembelajaran proyek berbasis fenomenologi pada matakuliah perkembangan peserta didik. Refleksi Pembelajaran Inovatif, 1(2), 115-122. https://doi.org/10.20885/rpi.vol1.iss2.art2

Minister of Education and Culture of the Republic of Indonesia. (2014). Peraturan Menteri Pendidikan 
Dan Kebudayaan Republik Indonesia Nomor 49 (11 ayat 1).

Ningtyas, E. S., \& Wuryani, E. (2017). Penerapan Model Pembelajaran Kooperatif (Cooperative Learning) Tipe Make-A Match Berbantuan Media Komik Interaktif Untuk Meningkatkan Aktivitas Belajar Dan Hasil Belajar IPS. Jurnal Pendidikan Surya Edukasi (JPSE), 3(1), 66-74.

Nugroho, B. H. (2019). Efek pembelajaran kooperatif dalam proses pembelajaran dan pencapaian tujuan pembelajaran pada mata kuliah pharmaceutical engineering. Refleksi Pembelajaran Inovatif, 1(2), 136-146. https://doi.org/10.20885/rpi.vol1.iss2.art4

Nugroho, U., \& Edi, S. S. (2009). Penerapan pembelajaran kooperatif tipe STAD berorientasi keterampilan proses. Jurnal Pendidikan Fisika Indonesia, 5(2).

Permanasari, R. C. (2014). Improving Students' Speaking Skill Through Three Steps Interview Technique(An Action Research of the Tenth Grade Students of SMK Negeri 9 Semarang in the Academic Year of 2013/2014). 1-180.

Purwaningsih, T. (2020). Penerapan blended learning melalui inisiasi pembelajaran online menggunakan website dan Google Hangout dengan melibatkan praktisi industri sebagai upaya peningkatan kualitas pembelajaran di kelas business environment. Refleksi Pembelajaran Inovatif, 1(2).

Ratnawati, S. R., Yuliasri, I., \& Hartono, R. (2018). Enhancing the Students' Speaking Skill Using Three Step Interview and Numbered Heads Together. Language Circle: Journal of Language and Literature, 12(2), 173-181. https://doi.org/10.15294/lc.v12i2.14176

Rohyami, Y., \& Huda, T. (2019). Pengaruh cooperative learning dan flipped classroom-cooperative learning matakuliah kimia analisis II terhadap motivasi belajar mahasiswa. Refleksi Pembelajaran Inovatif, 1(2), 147-160. https://doi.org/10.20885/rpi.vol1.iss2.art5

So, H.-J., \& Brush, T. A. (2008). Student perceptions of collaborative learning, social presence and satisfaction in a blended learning environment: Relationships and critical factors. Computers \& education, 51(1), 318-336.

Sutisna, A. (2016). Pengembangan Model Pembelajaran Blended Learning pada Pendidikan Kesetaraan Program Paket $\mathrm{C}$ dalam Meningkatkan Kemandirian Belajar. JTP-Jurnal Teknologi Pendidikan, 18(3), 156-168.

Tang, C., \& Chaw, L. (2013). Readiness for blended learning: Understanding attitude of university students. International Journal of Cyber Society and Education, 6(2), 79-100.

Teng, M. F. (2020). The effectiveness of group, pair and individual output tasks on learning phrasal verbs. The Language Learning Journal, 48(2), 187-200.

Ushioda, E. (2008). Motivation and good language learners. na.

Vygotsky, L. (1978). Interaction between learning and development. Readings on the development of children, 23(3), 34-41.

How to cite: Hidayah, F. N. (2020). Implementing a Cooperative E-Learning Model by Virtual Interviews with Native Speakers. Teknodika, 19 (1), 22-30. DOI: https://doi.org/10.20961/teknodika.v19i1.47677 